\author{
Paweł FRANKOWSKI \\ Jagiellonian University in Kraków \\ pawel.frankowski@uj.edu.pl
}

\title{
OUTER SPACE AND PRIVATE COMPANIES
}

\section{CONSEQUENCES FOR GLOBAL SECURITY}

ABSTRACT The paper focuses on sectors, methods, and spheres of the space activity of private companies, to provide empirical analysis of space applications and implications for global security. Special emphasis has been given to private companies offering access to satellite imagery and satellite remote sensing, as well as companies entering outer space with new and prospective capabilities as space mining. The article explains the rising importance of geo-intelligence, space surveillance and telecommunication for global security and new kind of security challenges and vulnerabilities such as environmental problems in outer space or technological challenges to security. The author argues that profit-oriented companies play crucial role in new security environment in the US, efficiently changing the law and practice. Finally he points out that new and growing market for subcontractors in space applications raises questions on growing dependence on private resources in traditional sphere of state activity, namely security, in this case provided from and through the outer space.

Key words: space security, privatization, space power

\section{INTRODUCTION}

For years outer space has been an exclusive area of activity of space-faring powers, and due to strategic importance of outer space for space any private activity was just impossible. ${ }^{1}$ Geostrategic or geospatial factors for space exploration and quest for astropolitics, ${ }^{2}$

1 H. Kleinberg, "On War in Space", Astropolitics, vol. 5, no. 1 (2007), pp. 1-27, at <https://doi. org/10.1080/14777620701544600>.

2 E.C. Dolman, Astropolitik. Classical Geopolitics in the Space Age, London-Portland 2002, p. 157. 
pursued by the United States, Soviet Union, but also France were accompanied with an intrinsic aversion to the loss of strategic position in outer space. Politicians and military commanders at the beginning of space race intensely opposed private actors, but with progress of space exploration such opposition has diminished, and private actors, offering sector alternatives, or just being more flexible than state controlled industry. Private space endeavours, initially limited to subcontracting, gradually have taken important position in space sector both in the US and in Europe. Finally, space industry became a regular part of economic landscape in the US and Europe, being important from economic, but also strategic point of view. Nevertheless, such liberalisation and discussion over the role and place of private actors in security that has happened from 1990s onwards and is happening nowadays should by analysed from two, concurring and somehow overlapping perspectives. In the US and Europe discussions over privatization of security, and role of private actors often run in the opposite direction. When in European countries most of the debate is over whether or not some functions of the state and state resources should be transferred to private actors, in the United States most of the arguments are revolving around whether such functions should be first and foremost public. ${ }^{3}$ This important argument on different preferences and ideas on both sides of Atlantic is also valid with relation to space affairs. However, the effects of privatization of space affairs are not straightforward. Natural monopolies, established by space private companies in some sectors as satellite imagery, and retrenchments and cutbacks, important after economic crisis 2008 as useful vehicle of political messages to the constituencies, are strongly tied to logic and dynamics of liberalization within military affairs. Therefore there are good reasons for believing that logic of privatization in military has been adopted also to space affairs, when narrative on the sunk costs of existing public space policies, opposition coming from lobbies, but also still high enthusiasm over space exploration facilitated privatization turn in space affairs.

Since I argue that logic of space privatization has been intertwined with neo-liberal dynamics of privatization of public services, a fundamental question arises: why some governments seem to be much more willing to support private space actors than others. Deteriorating economic situation could be the key but it is an insufficient factor to understand such strategic choices over crucial resources for state security. The answer to this salient question may be concentrated around preferences, alternatives, and benefits (both immediate and indirect), when costs of failure could be diffusely distributed between number of private actors, and public agencies.

As mentioned earlier, when some space assets and services, like telecommunication services, from the very beginning of space exploration, have been in private hands, for other sector like space imagery or synchronizing services it was not an easy path. However, strategies geared towards more private involvement are intrinsically similar to strategies and justifications in other public services. John Donahue referring to the privatization of public services argues that the political choice between public and

S. Chesterman, A. Fisher, "Conclusion: Private Security, Public Order”, in iidem (eds.), Private Security,

Public Order. The Outsourcing of Public Services and Its Limits, Oxford 2009, p. 225. 
private services basically has two dimensions. The first concerns finance, and focuses on the questions whether or not individuals should pay for services individually, or maybe the same services should be provided by the state, with funds raised from taxation. Apart from financing, the second dimension focuses on performance, flexibility, and ability to adapt to changing circumstances. In general, this dimension should be analysed if services should be delivered from governmental level or provided by nonstate entity, with lesser attachment to procedures, red tape and managerial style of governing. ${ }^{4}$ Nevertheless, privatization of security and military services follows a slightly different logic, because after private companies acquired contracts to provide security services, provisions of such services will be still financed by public money. Therefore individuals' rights, transferred to the state, who is main security provider, have been shifted back to private entities, able and willing to provide such services. Already it should be obvious that the main source of income for private space industry are public actors, and space companies hardly can find other clients. For example 66\% of European space industry is coming from public sector, ${ }^{5}$ and only in 2015 European companies provided goods worth as much as $534 \mathrm{mln}$ EUR for military customers EUR. ${ }^{6}$

Privatization or private security often refers to private actors who provide utility services, after acquiring a state-owned company, in most of the cases 'privatized' for better performance or to lower the financial burden for the state. But private security could be also provided with new projects and services, worked out by private companies, and then adopted by the state as security measures. It could be an example of mobile telephony, or variety of techniques and services connected to face/shape/pattern recognition, developed by private entities. However, with their security means the states are natural monopolies as ultimate security providers, and as a consequence, can regulate market possibilities, with regard to services provided by private actors. These regulatory choices and standards usually vary from one state to another, and for example regulations on CCTV in European Union differ to far extent, despite regulatory pressures coming from supranational level. In the space security realm, clear example of state regulatory choices comes from satellite imagery industry, when private providers are restricted to sell high-quality pictures on the market, and despite technological possibilities cannot provide high-resolution optical or radar imagery to customers throughout the world. Nevertheless, the so-called shutter control is meant to prohibit imaging of particular area, providing high quality images, or companies are forbidden to collect or sell imagery of a particular country. For example, US companies cannot collect or sell imagery of Israel of better quality than those available from other commercial sources.

Literature on privatization of military services has expanded, especially after 2002 and involvement of private companies in Iraqi operation. When appreciating an outlook of different scholars dealing with private military companies it is worth to follow

J.D. Donahue, The Privatization Decision. Public Ends, Private Means, New York 1991, pp. 7-8.

ASD-Eurospace, The European Space Industry in 2015, Paris 2016, pp. 10-11.

6 Ibid., p. 13. 
Prado $^{7}$ and argue that transferring provisions of services to private hands or acquiring from private entities without developing independent system on state's behalf can be beneficial for the state for at least four reasons. First reason is price, and cost of private provisions could be lower because private companies can provide services with fewer people, with outsourced services, also to third countries. Price of military service, to far extent depends on costs of trained personnel, when private companies hire former soldiers, with completed training before. Moreover, the cost of public security services is based on the benefits coming to soldiers after their years of service. For example for overall military budget of the United States ( 1 trillion USD), more than 200 billion USD, has been spent for pensioners, veterans' benefits or retiree health services.

Secondly, the push for private security may result in more efficient usage of financial and human resources, and soldiers may perform more valuable duties. ${ }^{8}$ Therefore, PMCs can provide better service for the same price or the same services lowering the price. This will allow moving financial resources to another public service or arguing that public money has been better spent. Thirdly, with private security providers, states can avoid lengthy red tape procedures, with for example standardization of military procurements, time for mobilization and deployment. While such problems are important during armed conflict, they have also become more and more important during the planning of infrastructure, using assets, and regulating activity. The demand for more flexible and less troublesome activity in security realm is constantly increasing, both in Europe and in the Western Hemisphere.

Finally, governments may turn for private resources for the lack of choice, when the state does not have necessary technical or material capabilities to provide security services in a timely fashion. ${ }^{9}$ However, some authors suggest that looking for private solutions in security cannot be analysed in isolation from pressure coming from political processes in larger scale. ${ }^{10}$ Nevertheless, distinguishing between economic power of private actors, and lack of capacity on behalf of the state, as driving factors for privatization of security services not necessarily answers the question why space assets, crucial for power of any important state in the world politics, are developed by private actors, being to some extent neglected by governments.

Some authors argue that privatization of core state functions, such as security, is rather rare, and private security actors do not enjoy that kind of freedom as other actors in public-private partnership. ${ }^{11}$ Moreover, the main business of private security satellite providers is not in protection of life and assets or clear military activity, but commercial

M.M. Prado, "Regulatory Choices in the Privatization of Infrastructure", in S. Chesterman, A. Fisher (eds.), Private Security, Public Order..., pp. 110-111.

8 Ibid., p. 110.

9 Ibid.

10 R. Abrahamsen, M.C. Williams, Security beyond the State. Private Security in International Politics, Cambridge-New York 2011, pp. 25-26.

11 T. Risse, T.A Börzel, "Public-Private Partnerships: Effective and Legitimate Tools of Transnational Governance”, in E. Grande, L.W. Pauly (eds.), Complex Sovereignty. Reconstituting Political Authority in the Twenty-First Century, Toronto 2005, p. 202. 
services, to large extent used by governments. For such companies, even clearly involved into security matters, and who are part of struggles in security fields, is better to keep an image of highly specialized, knowledge-intensive, expertise-oriented providers of security oriented solutions. ${ }^{12}$

Privatization of space activities is based on cost-saving approach as a dominant may result in lack of administrative oversight. With outsourcing space activities, the very question of public scrutiny, as a part of democratic state, would be also less relevant. But also, when government turns to private operators, because it lacks capacity itself, and this is the case of European states, any meaningful competition may be impossible. Privatization of space security refers to the discussion of a state's responsibility for the space affairs. Nevertheless, as some authors point out, this responsibility can be problematic, since definition of responsibility remains vague, also from the perspective of possible implementation. ${ }^{13}$

\section{WHAT IS SPACE SECURITY?}

With regard to space security and private activities it is necessary to point out how this very widely-used term has been coined, and what is the contemporary understanding of space security, and how private actors could be merged into thinking about all policies and programs in terms of the implications for space affairs. Michael Sheehan aptly points out that space security and role of space for security have been discussed rather widely, and military dimension is still the most important part of such discussion. Nevertheless, other important issues are also included to the discourse on space security and the meaning of 'space security' started to be understood in more general way. But for Sheenan 'space security' is limited to space actors, namely states, who wish to use it for the socioeconomic benefits of their populations [...] increase human security and perceive space as ability to use space as vital national interest. ${ }^{14}$

Space security is perceived in three dimensions as (1) outer space for security (2) security in outer space (3) security from outer space. For the first dimension all defence purposes and using space for all security issues in analysed, when security in outer space relates to space system, and space sustainability of space activities. Third dimension of space security, a post-Cold War dimension, focuses on greater security of Earth, where environmental protection, weather forecasts, floods, droughts, but also rescue and disaster management are central themes of space endeavours. Jean Francis Mayence defines space security as three interrelated areas, as outer space for security, security in

12 R. Abrahamsen, M.C. Williams, Security beyond the State..., p. 41.

13 M. Fortheau, "Space Law", in J. Crawford, A. Pellet, S. Olleson (eds.), The Law of International Responsibility, New York 2010, p. 904.

14 M. Sheehan, "Defining Space Security", in K.-U. Schrogl et al. (eds.), Handbook of Space Security, New York 2015, p. 8. 
outer space, security from outer space. ${ }^{15}$ For Mayence security in outer space, dominated by public actors, as space faring nations or ESA, is also complemented by commercial stakeholders. However, private actors, apart from assessing political risk of possible destructions their satellites on the orbit, rather focus on reducing any financial impact on space business. A broader understanding of 'space security' encompasses issues concerning more than just activities occurring beyond Earth's atmosphere but all the elements of ground stations, and communication channels. ${ }^{16}$

However, after the end of the Cold War the boundaries between strictly military and civilian approach to space, as well as the military space sector and civilian actors have largely been blurred, when military commanders use civilian satellite systems to gain strategic information or use commercial telecommunication links for health services directly from a battlefield. For example, during the Gulf War international commercial satellites provided services for field commanders and leased mobile satellite terminals used in the theatre of war connected communications systems with headquarters facilities in Florida.

Nevertheless, apart from positive examples of cooperation between private and public actors, Sheehan argues that outer space can produce both security and insecurity, therefore private companies active in outer space could apart of providing security with space assets can generate threats in outer space, from outer space, and also through outer space. ${ }^{17}$ Possible threats may include, among others, disruption of satellite signal, creation of space debris, potentially dangerous influence on Earth (destruction of object on Earth), but also protection of private data gathered from satellite imagery.

\section{SPACE GOVERNANCE AND SPACE SECURITY}

Space governance can be studied from different perspectives, however, established links between the predominance of public actors with particular space assets, and still small number of space private companies greatly limits comparative work to two regions, the US and Europe. However one aspect of space governance is especially puzzling, namely growing role of private governance, when public actors deliberately and somehow consciously disengaged with regulations for space security. This international governance, when it comes to space security, has been divided into two intertwined models of global commons and strategic stability. When the model of global commons relates to voluntary action, and self-restraint, the model of strategic stability is more sophisticated where commercial benefits are also included..$^{18}$ However, neither the global commons nor the strategic stability model looks deeply into relations between private and pub-

15 J.F. Mayence, "Space Security: Transatlantic Approach to Space Governance", in J. Robinson et al. (eds.), Prospects for Transparency and Confidence-Building Measures in Space Report, Vienna 2010, p. 35.

M. Sheehan, "Defining Space Security", p. 12.

17 Ibid., p. 15.

18

E. Sadeh, “Obstacles to International Space Governance”, in K.-U. Schrogl et al. (eds.), Handbook..., p. 24. 
lic approach to space security. This is mainly due to the fact that revenues from commercial space activity (195 billion US dollars) with almost $80 \%$ comes from satellite television services. ${ }^{19}$ Satellite imagery, remote sensing or future space mining, are less important for commercial actors, and they to large extent cooperate or coordinate their behaviour with national governments.

However, sometimes private actors are so powerful that they are able to control legislation in pre-emptive manner, when technology cannot keep up with proposed legislation. This is certainly the case of Commercial Space Launch Competitiveness Act (SPACE Act of 2015), signed by the President of the United States in 2015. This act, which is the culmination of efforts of the American private sector, opens up new opportunities for private companies in terms of not only launching heavy lift of cargo and humans, but primarily commercial exploration and recovery of space assets by the citizens of the United States. Such act allows US citizens to obtain, possess, transport, use and sell space assets in accordance with US law and international law. SPACE Act of 2015 contains a clause stating that adoption of this act it does not mean taking possession or exclusive rights to any celestial body. Nevertheless, the importance of the adopted legislation goes far beyond the Outer Space Treaty of 1967, which is also a party to the United States. Although currently owned technology does not allow starting exploration of asteroids by private companies, the SPACE Act should be understood as an attempt to impose legal arrangements for which will follow other powers. Despite the ban on the appropriation of space contained in the Space Treaty, there are no clear international legal regulations concerning the possibility of acquiring space assets. ${ }^{20}$ Moreover, commercial entrepreneurs, who will decide to explore outer space and start mining activities would be not bound by any specific positive or negative obligations regarding the benefits of such activity. The only limitations for commercial actors will be to ensure that space mining do not interfere with states' rights. ${ }^{21}$ Such legal gap and security gap would allow private companies to regulate, at least at the very beginning, all rules for environmental issues.

This pre-emptive regulation and legislation follows the logic of the Moon Treaty, international regulation which regulates the activities of states on the Moon and other celestial bodies, adopted in 1979. The Moon Treaty, in fact not signed by space-faring states as the US or Russia, contains a commitment to establish a regime laying down the rules of international exploration of the Moon, when this becomes possible. ${ }^{22}$ SPACE

19 C. Al-Ekabi, "European Space Activities in the Global Context", in idem et al. (eds.), Yearbook on Space Policy 2014. The Governance of Space, Wien 2016, p. 52.

20 B. Kellman, "On Commercial Mining of Minerals in Outer Space: A Rejoinder to Dr Ricky J. Lee”, Air and Space Law, vol. 39, no. 6 (2014), pp. 411-420.

21 Ibid., p. 413.

22 J. Blamont, “US Space Exploration Strategy: Is There a Better Way?”, Space Policy, vol. 28, no. 4 (2012), pp. 212-217, at <https://doi.org/10.1016/j.spacepol.2012.09.009>; P. Finarelli, I. Pryke, "A New Paradigm for International Cooperation in Space Exploration”, Space Policy, vol. 21, no. 2 (2005), pp. 97-99, at <https://doi.org/10.1016/j.spacepol.2005.02.006>; T. Gangale, The Development of Outer Space. Sovereignty and Property Rights in International Space Law, Santa Barbara 2009. 
Adoption Act of 2015 is a response to the plans of two US companies: Deep Space Industries and Planetary Resources, planning to start mining asteroids before 2023 using nano-satellites. The first cargo of raw materials or re obtained from asteroids to be brought back to Earth in 2018. Supporters of the Commercial Space Act emphasize that this act fills the gap in uncharted and non-regulated area of space practice, but does not violate international law, and the turnover of materials derived outside of the Earth is a fact. The concept of exploitation of space assets and the provision of harvested 'spoil' to Earth is unprofitable from an economic point of view. However, some experts suggest that in the foreseeable future, space mining companies will be able exploit raw materials for the production of fuel in orbit and replenishment satellites whose design allows for such a possibility. ${ }^{23}$ In addition, raw materials or partially processed ore may be used for microgravity metallurgy and 3D printing, which opens new prospects for the use of space. The second option which opens for American companies could be a recovery of inactive satellites orbiting on the so-called graveyard orbit by repairing and refuelling by fuel extracted from exploitation of asteroids. Private actors operating from territory of any state, which would be the first to reach the possibility of using such technology will gain an advantage that will change the balance of power in orbit, and also will have an impact on privatization of space security. Since decommissioned satellites are often sold to international consortia or third states without any interests in satellite operations refuelling of inactive or abandoned satellites should be treated as kind of refurbishing activity with elements found on the space scrap yard. Contemporary international law does not devise any mechanism to prevent such hijacking, and ideas behind refuelling are rather positive, and based on environmental assumptions, than on any parallel with piracy or stealing. Therefore pre-emptive national legislation, supported by private entities can be characterized as reversed coordination, when commercial players, motivated by prospective benefits, are able to craft and coordinate space activities without tested technology in hand.

Entering the orbit by private actors also changes the practice of safety spacecraft, which gradually will be provided by private contractors offering not only the possibility to launch a cargo, but also, for example, a cheaper, and more effective space debris reduction system (SDRS) suited to the needs of SDRS'stakeholders. An attempt to regulate uncharted area of international law, and manoeuvring within the gap in international regulations by powerful commercial actors is clearly an example of privatization of security, and for some reason governments gave private companies carte blanche in space mining.

Such carte blanche, or naïve assumption that contemporary technology can be still controlled by the governments has been also visible in remote sensing and satellite imagery. Historically the United States played a crucial role in remote sensing, and images taken from Earth orbit were used to military purposes. But decision taken by French government to create Satellite Pour l'Observation de la Terre (SPOT) company, operating on commercial terms, and selling images to other states, and private customers

23 J.C. Moltz, Crowded Orbits. Conflict and Cooperation in Space, New York 2014, pp. 110-111. 
altered the position of United States. Nowadays space imagery is accessible for almost everyone, and thanks to detailed images provided by commercial providers, contemporary understanding of international security must be changed. Just to think behind the frames of national security, when high resolution commercial imagery can be accessed by actors involved in security issues, but also actor as universities, media, insurance companies, or even individual who can buy images from commercial sources. When private actors have sensing capabilities, their possible impact on security, starting from NGOs and human rights organisations to individuals, would complement traditional security measures rather than focus entirely on space security as such. However, thanks to Google Maps, actors like terrorists or insurgency forces can plan in more detailed and effective way, and analyse their attacks in the context of spatial relationship in a way unavailable 15 years ago.

\section{IS IT REALLY PRIVATE SPACE SECURITY?}

Privatization of space security and outsourcing affects states' regulatory possibilities, when not always lead to more efficient allocation of resources. States may look for private resources to avoid regulatory barriers or democratic scrutiny, but also when they do not have enough resources to perform some duties. Also, governments may turn to private actors to start meaningful competition in the market. But to be effective such competition requires multi-stakeholder participation, when space market is still specific. For example, Digital Globe has a very strong purchasing power as market global leader for Earth observation services with $63 \%$ of worldwide market shares ${ }^{24}$ when Airbus DS Geo-Intelligence have 14\%, and Planet Labs 5\% respectively. More than one-third of customers are from defence and intelligence area. Thus, if we want to understand the choices taken by private companies, even commercial satellite companies operate using market strategy and criteria, we should not forget that they get most of their income from public orders. Therefore the biggest market for private companies is, in fact, the government, and any assumption about privatization of security regarding image sensing seems to be far-fetched. Currently, there are three important arguments against clear divide between public and private interests in space.

Firstly, public policies regarding private space operators seem to contradict liberal assumptions, and what one would expect of relations public and private bodies. Private companies, as DigitalGlobe or Spot Image can exist because they sell images to government agencies. As some authors suggest, from a conventional and rationalist perspective, the answer to this puzzle is based on the fact that some of the image sensing companies were created by governments (SPOT) or largely supported by long-term contracts. Thus public contracts serve as major source of revenue, when other services like Google Maps or Bing, are less important. For example DigitalGlobe's principal

24 European Commission, Study to Examine the Socio-economic Impact of Copernicus in the EU. Report on the Copernicus Downstream Sector and User Benefits. Written by PwC, Brussels 2016, p. 19. 
customer is the U.S. National Geospatial-Intelligence Agency (NGA), based on the EnhancedView Service-Level Agreement (SLA). Therefore up to 60\% of revenues comes from public resources, with total revenue more than 700 million US dollars. ${ }^{25}$ Such dependence on one partner forces other customers, mainly other government agencies, to use limited satellite time, regardless preferential treatment for 10 Direct Access Partners. Even SpaceX, private company, aiming at developing reusable rocket with first reusable stage (Falcon 9), to compete with public launchers by means of price, receives funding from state-funded agency Space Florida up to 7.3 million US dollars. ${ }^{26}$ The company benefited from NASA and Department of Defence contracts as well. Nevertheless, space activities conducted by private operators with imaging capacity, and their relations with government cannot be compared with other space activities like telecommunication. Being most profitable part of the satellite market, telecommunication companies with developed space assets private security satellite providers are working closely with military; and their assets are used for defence sectors for years. However, when DigitalGlobe or SpotImage can exist thanks to long term contracts, without any direct competitor, the big commercial operators such as Eutelsat, Intelsat General, SES Government Solutions and Inmarsat are selling their services to American Department of Defense (American Air Force and the Defence Information Systems Agency) on year-contracts. This situation results from competition on the comsat market, but also from different priorities envisaged every budget year. Planning overseas operations military operators demand different levels of services every year, and don't want be bound with long term contracts or other arrangements. While it seems to be beneficial for public funds, in fact the spot market demands higher prices, and long term agreements between governments and private operators may significantly decrease military spending. Some authors suggest that with purchasing commercial satellite bandwidth individually on the spot market European governments might pay more than 60 million USD premium. ${ }^{27}$ But higher income for comsat operators not necessarily turns into win-win situation, because the demand from governments outpaces satellites capacity, and any investment into new technology made by private operators is not profitable as it seems to be.

One of the recent examples of merging private and public interests could be the European Data Relay System (ERDS), based entirely on private resources. ERDS provides access to data transmitted from the orbit to ground stations with a high-speed laser satellite links, based on Eutelsat-9B, placed in orbit $29^{\text {th }}$ of January 2016. This system is the first European telecommunications system based on laser links capable of transmitting information at a rate $1.8 \mathrm{Gbit} / \mathrm{s}$. Eutelsat, private consortium, leased part of the satellite for ERDS, and from January 2016 a distinction between public and private in-

25 P.B. de Selding, "For DigitalGlobe, Government Business Steady but Commercial Disappoints", Space News, 30 October 2015, at <http://spacenews.com/for-digitalglobe-government-business-steady-butcommercial-disappoints/>, 7 January 2016.

26 C. Al-Ekabi, “European Space Activities...”, p. 67.

27 Idem, "European Space Activities in the Global Context", in idem et al. (eds.), Yearbook on Space Policy 2011/2012. Space in Times of Financial Crisis, Wien 2014, p. 89. 
terests in space security blurred. Moreover EDRS has been funded by a public-private partnership between ESA and Airbus Defence and Space, with Airbus operating the service and the DLR German Space Administration decided to cover the costs of the development of the laser terminal. ${ }^{28}$ ERDS, unlike existing systems of satellite communications, which in order to transmit data must be in the range of ground stations, collects data through a laser link from European Sentinel satellites, and then transmits to ground stations. The data transmission will take place in real time, and regular data transmission started in mid-2016. Another one of the satellites equipped with ERDS will be placed in orbit in 2017, and in 2020 ERDS will cover the entire globe. In the future, the system will be used to transmit data from drones, which will significantly change the prospect of European security, as these figures will concern both the EU's external borders and areas where military operations are conducted. Satellite laser communications is very important dimension of providing security; it is worth noticing that on January 27, 2016, the satellite Intelsat 29e was put on Earth orbit, whose main task is to transmit real-time video signal from unmanned American aircrafts providing ISR (Intelligence, Surveillance, Reconnaissance) data. It is estimated that the current demand for transmission (over 300 video streams) only for CENTCOM is covered only in $20 \%$, and the new satellite Intelsat is expected to improve this ratio. This shows both the scale of the phenomenon of the use of drones for intelligence activities, as well as the potential for those involved in the exploration of outer space, but mostly involvement and role of private actors in security services provided from outer space.

The second argument concerning tendency to focus on a limited set of possible private goals and strategies has been excluded from the discourse on privatization of space affairs and space security. Public and private interests are intertwined, and thanks to lobbies public agencies may create an impression that by buying services from private operators public interests are managed better, without unnecessary financial risk on governmental side. This argument could contribute to understanding the unique process of privatization of space security, when prices of space products and services have decreased, and space services have become part of the essential fabric of the global econo$m y .{ }^{29}$ Commercial involvement in space services inevitably translates into closer links between lobbies and public administration, and services with high demand on public side have been outsourced to private operators. This is the case of telecommunication, but also aforementioned satellite imagery.

Privatization of space security has continued, and the space industry has taken a leading role in debates over regulation of future activities and acts through strategic constellations. For example in December 2015 the Washington Space Business Roundtable hosted a meeting for military decision-makers with experts from satellite industry to discuss integration of commercial satellite communications services into

28 "First SpaceDataHighway Laser Relay in Orbit", ESA, 30 January 2016, at < http://www.esa.int/Our_ Activities/Telecommunications_Integrated_Applications/EDRS/First_SpaceDataHighway_laser_ relay_in_orbit>, 3 February 2016.

29

J.C. Moltz, Crowded Orbits..., p. 102. 
the National Security Space architecture. ${ }^{30}$ Such integration means planning of future infrastructure, long term contracts, sharing the cost of launching and satellite operation, and hosted payloads aboard commercial satellites. Merging private interests, with truly military goals and means, should be perceived as a long term strategy for commercial operators, especially when commercial space assets have been used for information sharing, intelligence gathering and transmission of signals to remotely piloted aircraft operations. But on the other hand, commercial operators cannot guarantee that their satellites will be resilient enough to confront with intercepting, jamming, disabling or even destruction of satellites and satellite transponders.

From IPE perspective, outsourcing security assets to one private operator, with a long term contract and steady market for services could be mutually profitable, but when public administration relies only on singe provider, any turmoil or lack of service can undermine strategic stability for weeks. Short-sighted plans of privatization of vital assets are visible in American launching sector, when United Launch Alliance, due to a hefty deal with NPO Energomash, Russian producer of RD-180 rocket engine, changed strategic balance in space. After the crisis in Ukraine, and growing tensions between American and Russian government, ULA has been unable to provide constant launching capability for military purposes. Similar situation took place when Aerojet engines NK-33, produced by Russian manufacturer Kuznetsov, were imported and used in Anteres rocket.

However, the traditional way of thinking about space assets includes big (more than $500 \mathrm{~kg}$ ) satellites available only to powerful states and rich corporations, with necessary heavy lift capabilities. Nowadays, with the expansion and continuing process of miniaturization of electronic parts, less powerful states or even private persons could own their own cubesat or other small satellite, when costs of payload are less than few millions dollars. This dramatic shift in cost of manufacturing and launching satellites may change the relations between public and private sphere from coordination and cooperation to coexistence and even conflict, when a good number of new artificial objects on low Earth orbit may generate space debris without any control and responsibility. UN Convention on International Liability for Damage Caused by Space Objects points out that the launching state should be responsible for any object placed on Earth orbit. But nowadays, when satellites are smaller and without much manoeuvring ability, and sometimes belonging to a multinational consortium, proving such responsibility would be complicated. ${ }^{31}$

Lyall and Larsen argue that apart from tradition problems with liability of private actors in outer space, and inconsistency of space law with current strategic and market situation, private commercial users of outer space operate on the basis of private

30 R. Schradin, "Government Space Leaders Look to Commercial Satellites for More Resilient Communications”, GovSat, 5 January 2016, at < http://www.ses-gs.com/govsat/defense-intelligence/governmentspace-leaders-look-to-commercial-satellites-for-more-resilient-communications/>, 28 January 2016.

31 P. Haanappel, "Enforcing the Liability Convention: Ensuring the Binding Force of the Award of the Claims Commission", in M. Benkö, K.-U. Schrogl (eds.), Space Law. Current Problems and Perspectives for Future Regulation, Utrecht 2005, pp. 113-120. 
law. Therefore, from construction of satellites, through launching, market of securities, and possible dispute solving, commercial operators are regulated by private as well as by public laws. In result, without international consent on the shape and content for binding legal provisions for private commercial operators, countries must have to look onto specialised national space legislation. When it comes to traditional space-faring powers, like the US or Australia, those states enjoy fairly developed domestic legal standards, but those without specialized national legislation - when the disputes arise from the performance of contracts related to the space activity - are unprivileged..$^{32}$ Therefore with lack of proper international legislation, and their inability to overthrow private litigation, disputes between private operators, intergovernmental organizations, and states are resolved on the merit of legislation in other states. ${ }^{33}$

Third argument relates to the absence of real competition between major commercial operators, mostly in launching market. Only 23 out of 75 launchers in the globe are commercially competed, ${ }^{34}$ but sound business spaceflight commercial operators should base, for the time being, on contracts provided by public agencies. Without long term flow (or viable prospect of flow) of public money, any reasonable investment in the space resources by commercial operators will be not attractive for potentially interests entrepreneurs. On the other hand, public entities, being aware of role of private entrepreneurs on satellite market, as Surrey Satellite Technology Ltd., are in the position to acquire majority of shares, to get an access to technology and information produced by such companies. Therefore Surrey Satellite Technology has been acquired by EADS, and from a real private entity in space affairs after 25 years it became one of branches of a state controlled consortium. Setting aside cost and the problem that public agency decided to control private actor, this is an example for a long term tendency towards competition in space security between private and public parties. An example of deal between Surrey Satellite Technology and EADS may persuade other commercial operators to follow the same strategy. Other examples of not-so-full privatization of space come from Germany, where very high resolution multi-mode X-Band SAR satellite TerraSAR-X, launched in 2007, is operated by the German Space Agency and the company EADS ASTRIUM as a Public Private Partnership (PPP). It is worth stressing that EADS ASTRIUM is a company where the majority of shares belong to European Aeronautic Defence and Space Company (EADS), therefore private component in PPP is rather unimportant.

When European space security market is largely dominated by EADS, and market criteria are subdued to states' interests, Fitzsimmons argues that the American security market could be characterized as neoliberal, and private companies provide services to governments on regular basis. Moreover, American bureaucracy, combined with outsourcing and downsizing of U.S. Armed Forces, and a relatively unrestricted legal and reg-

32 F. Lyall, P.B. Larsen, Space Law. A Treatise, Farnham 2009, p. 468.

33 A. Mourre, "Arbitration in Space Contracts", Arbitration International, vol. 21, no. 1 (2005), pp. 37-58, at <https://doi.org/10.1093/arbitration/21.1.37>.

34 J.C. Moltz, Crowded Orbits..., p. 96. 
ulatory environment results in the development of the market for security providers. ${ }^{35}$ Whereas it makes a good deal of sense for traditional approach to PMCs, also could be useful for understanding a large scale involvement of private satellite services providers in the United States. In Europe, however, which is dominated by regulations and where lack of coherence of satellite market is more than visible, and privatization of satellite services is based on ostensible public-private partnership. European actors in the position to sell satellite security services, are, in fact, controlled by European states through variety of consortia, where governments are major stakeholders, like in EADS.

\section{POSSIBLE SCENARIOS FOR PRIVATIZATION OF SPACE SECURITY}

In the terms of privatization and space security, space remains relatively untapped, but commercial and military benefits from space exploration/exploitation could even lead to 'privatization of space'. Such privatization will result from growing pressure on spacefaring countries to defect from cooperation, since is less viable with good number of multiple actors who entered the space. ${ }^{36}$ However, space policy and space research are characterized by very high costs, which are rather impossible to bear by private companies, limited by economic calculation. As pointed out earlier, under-investment in technological development by private companies it is related to the fact that these actors are not focused on profits of a social nature, such as improving the quality of life of the recipient of the product. ${ }^{37}$ This makes some technology, potentially beneficial to society, not developed or introduced into use, because the profit margin is too small to make this viable for commercial players.

To conclude, privatization of space security can develop in unexpected way, but in today's space environment private actors would rather play the role of security regulators than security providers. When investment in space technologies is less profitable than other areas of economy, private actors would focus on soft law and conflict prevention in space, and new private initiatives will appear. For example, apart from important space companies, as SpaceX or Blue Origin active in outer space, other private actors as Secure World Foundation (SWF), who focus on space sustainability, will play more important role in crafting international guidelines for space activities. ${ }^{38}$ This path the way for future solutions and projects, as cleaning the space debris, extracting resources from asteroids and planetoids, refuelling satellites, providing payload capabili-

35 S. Fitzsimmons, "The Market for Force in the United States", in M. Dunigan, U. Petersohn (eds.), The Markets for Force. Privatization of Security across World Regions, Philadelphia 2015, p. 158.

36 J.C. Moltz, The Politics of Space Security. Strategic Restraint and the Pursuit of National Interests, Stanford 2008, p. 34 .

37 A.N. Link, J.T. Scott, Public Goods, Public Gains. Calculating the Social Benefits of Public R\&D, New York-Oxford 2011, p. 5.

38 T. Hitchens, Future Security in Space. Charting a Cooperative Course, Washington 2004. 
ties for governmental entities on market-based logic, will be based on activity non-state actors, providing soft law and regulatory solutions, where space faring states are unable to find any compromise. Therefore private companies will be in fact global (or space) regulators, as part of UNCOPUS, being involved in space activities. ${ }^{39}$

The last argument for private involvement in space security comes from an approach based on common good and resilience of space assets, emphasized by the Project Ploughshares, as an important part of space security. As of 2017 there are more than 700,000 man-made objects on the Earth's orbit bigger than $1 \mathrm{~cm}$, while 17,000 of them are bigger than $10 \mathrm{~cm} \cdot{ }^{40}$ Some of them are traced by SSA systems, both American and European, but these systems are public-military owned, and private operators are not granted any access to this data. Any collision of space object with space debris, even with small particles, might result in a chain reaction, called Kessler's syndrome, and not only private but public, and military assets will be destroyed or impaired. In such conditions, a reluctant cooperation between the public and private sector, and unwillingness to share vulnerable data by public actors seem to confirm that private space activity is more than necessary. This is an apparent case when logic of mistrust between state powers must be overcome by private actors, perhaps by suggesting common preferences for debris mitigation, and space situational awareness. In the case of space debris, Space Data Association, an initiative supported by private sector, with its main aim to enhance data sharing between commercial satellite operators, could be an example of nascent public good provided by private actors for the sake of global security.

\section{BIBLIOGRAPHY}

Abrahamsen R., Williams M.C., Security beyond the State. Private Security in International Politics, Cambridge-New York 2011.

Al-Ekabi C., "European Space Activities in the Global Context", in C. Al-Ekabi et al. (eds.), Yearbook on Space Policy 2011/2012. Space in Times of Financial Crisis, Wien 2014.

Al-Ekabi C., "European Space Activities in the Global Context", in C. Al-Ekabi et al. (eds.), Yearbook on Space Policy 2014. The Governance of Space, Wien 2016.

ASD-Eurospace, The European Space Industry in 2015, Paris 2016.

Blamont J., “US Space Exploration Strategy: Is There a Better Way?", Space Policy, vol. 28, no. 4 (2012), at <https://doi.org/10.1016/j.spacepol.2012.09.009>.

39 G. Brachet, "The Origins of the 'Long-term Sustainability of Outer Space Activities' Initiative at UN COPUOS”, Space Policy, vol. 28, no. 3 (2012), pp. 161-165, at <https://doi.org/10.1016/j.spacepol. 2012.06.007>.

40 B. Schmidt-Tedd, N. Hedman, A. Hurtz, "The 2007 Resolution on Recommendations on Enhancing the Practice of States and International Intergovernmental Organisations in Registering Space Objects", in S. Hobe et al. (eds.), Cologne Commentary on Space Law, vol. 3, Köln 2015, p. 464. 
Brachet G., "The Origins of the 'Long-term Sustainability of Outer Space Activities' Initiative at UN COPUOS”, Space Policy, vol. 28, no. 3 (2012), at <https://doi.org/10.1016/j.spacepol.2012.06.007>.

Chesterman S., Fisher A., "Conclusion: Private Security, Public Order”, in S. Chesterman, A. Fisher (eds.), Private Security, Public Order. The Outsourcing of Public Services and Its Limits, Oxford 2009.

Dolman E.C., Astropolitik. Classical Geopolitics in the Space Age, London-Portland 2002.

Donahue J.D., The Privatization Decision. Public Ends, Private Means, New York 1991.

European Commission, Study to Examine the Socio-economic Impact of Copernicus in the EU. Report on the Copernicus Downstream Sector and User Benefits. Written by PwC, Brussels 2016.

Finarelli P., Pryke I., "A New Paradigm for International Cooperation in Space Exploration", Space Policy, vol. 21, no. 2 (2005), at <https://doi.org/10.1016/j.spacepol.2005.02.006>.

"First SpaceDataHighway Laser Relay in Orbit", ESA, 30 January 2016, at <http://www. esa.int/Our_Activities/Telecommunications_Integrated_Applications/EDRS/First_ SpaceDataHighway_laser_relay_in_orbit $>$.

Fitzsimmons S., "The Market for Force in the United States”, in M. Dunigan, U. Petersohn (eds.), The Markets for Force. Privatization of Security across World Regions, Philadelphia 2015.

Fortheau M., "Space Law”, in J. Crawford, A. Pellet, S. Olleson (eds.), The Law of International Responsibility, New York 2010.

Gangale T., The Development of Outer Space. Sovereignty and Property Rights in International Space Law, Santa Barbara 2009.

Haanappel P., "Enforcing the Liability Convention: Ensuring the Binding Force of the Award of the Claims Commission”, in M. Benkö, K.-U. Schrogl (eds.), Space Law. Current Problems and Perspectives for Future Regulation, Utrecht 2005.

Hitchens T., Future Security in Space. Charting a Cooperative Course, Washington 2004.

Kellman B., "On Commercial Mining of Minerals in Outer Space: A Rejoinder to Dr Ricky J. Lee”, Air and Space Law, vol. 39, no. 6 (2014).

Kleinberg H., "On War in Space”, Astropolitics, vol. 5, no. 1 (2007), at <https://doi. org/10.1080/14777620701544600>.

Link A.N., Scott J.T., Public Goods, Public Gains. Calculating the Social Benefits of Public R\&D, New York-Oxford 2011.

Lyall F., Larsen P.B., Space Law. A Treatise, Farnham 2009.

Mayence J.F., "Space Security: Transatlantic Approach to Space Governance”, in J. Robinson et al. (eds.), Prospects for Transparency and Confidence-Building Measures in Space Report, Vienna 2010.

Moltz J.C., Crowded Orbits. Conflict and Cooperation in Space, New York 2014.

Moltz J.C., The Politics of Space Security. Strategic Restraint and the Pursuit of National Interests, Stanford 2008.

Mourre A., "Arbitration in Space Contracts", Arbitration International, vol. 21, no. 1 (2005), at <https://doi.org/10.1093/arbitration/21.1.37>.

Prado M.M., "Regulatory Choices in the Privatization of Infrastructure”, in S. Chesterman, A. Fisher (eds.), Private Security, Public Order. The Outsourcing of Public Services and Its Limits, Oxford 2009. 
Risse T., Börzel T.A., "Public-Private Partnerships: Effective and Legitimate Tools of Transnational Governance”, in E. Grande, L.W. Pauly (eds.), Complex Sovereignty. Reconstituting Political Authority in the Twenty-First Century, Toronto 2005.

Sadeh E., "Obstacles to International Space Governance”, in K.-U. Schrogl et al. (eds.), Handbook of Space Security, New York 2015.

Schmidt-Tedd B., Hedman H., Hurtz A., “The 2007 Resolution on Recommendations on Enhancing the Practice of States and International Intergovernmental Organisations in Registering Space Objects", in S. Hobe et al. (eds.), Cologne Commentary on Space Law, vol. 3, Köln 2015.

Schradin R., "Government Space Leaders Look to Commercial Satellites for More Resilient Communications", GovSat, 5 January 2016, at <http://www.ses-gs.com/govsat/defenseintelligence/government-space-leaders-look-to-commercial-satellites-for-more-resilientcommunications/ $>$.

Selding P.B. de, "For DigitalGlobe, Government Business Steady but Commercial Disappoints", Space News, 30 October 2015, at <http://spacenews.com/for-digitalglobe-governmentbusiness-steady-but-commercial-disappoints/ $>$.

Sheehan M., "Defining Space Security”, in K.-U. Schrogl et al. (eds.), Handbook of Space Security, New York 2015.

Paweł FRANKOWSKI - Jagiellonian University, Assistant Professor at the Faculty of National Security. His current research interests include space policy, labour standards in free trade agreements, and theories of international relations. 